\title{
ANALISIS PENGARUH KEPEMIMPINAN, MOTIVASI DAN DISIPLIN KERJA TERHADAP KINERJA KARYAWAN CV. RORIS TEKNIK TANGERANG
}

\section{Annysa Mardany, Dhadar Wulandari, Yuni Herlinda Hutabarat}

Universitas Budi Luhur Jakarta, Indonesia

Email: 1931600777@ student.budiluhur.ac.id,931600793@student.budiluhur.ac.id, 1931600876@student.budiluhur.ac.id

\begin{abstract}
Abstrak
Sumber daya manusia suatu perusahaan perlu dikelola secara benar agar tercipta antara kebutuhan pegawai dengan tuntutan dan kemampuan perusahaan tersebut. Penelitian ini bertujuan untuk mendeskripsikan masalah yang ada pada CV. Roris Teknik yang dimana Perkembangan sektor bisnis jasa perbaikan eltronik dan kelistirikan menjadi peluang bagi perusahaan kecil untuk sub pekerjaan sektoral. Memanfaatkan peluang dalam meraih konsumen, menciptakan persaingan antara perusahaan-perusahaan jasa perbaikan serupa. Hal ini juga membuat setiap perusahaan harus menginovasi strategi pemasaran yang kreatif dalam menjual jasa yang ditawarkan kepada target sasaran. CV. Roris Teknik merupakan salah satu perusahaan jasa, yang berdiri pada tahun 2013 dan bergerak di bidang jasa perbaikan elktrinik dan kelistrikan. Kendala yang sering terjadi adalah ketika jadwal pengerjaan proyek yang dalam keadaan inilah perlunya arahan pimpinan, motivasi perusahaan dan disiplin kerja yang baik antar bidang kerja di CV. Roris Teknik agar bisa di tindak lanjuti kinerja karyawan sesegera mungkin sehingga tidak menimbulkan kekecewaan dari konsumen. Berdasarkan uraian diatas, maka penulis tertarik untuk mengadakan penelitian yang akan dituangkan dalam bentuk tulisan ilmiah yang berjudul Analisis Pengaruh Kepemimpinan, Motivasi dan Disiplin Kerja Terhadap Kinerja Karyawan CV. Roris Teknik Tangerang.
\end{abstract}

Kata Kunci: kepemimpinan; motivasi dan disiplin kerja; kinerja pegawai

\section{Abstract}

The human resources of a company need to be managed properly in order to be created between the needs of employees and the demands and capabilities of the company. This research aims to describe the problems that exist in CV. Roris Teknik where the development of the business sector of electronic repair services and electricity becomes an opportunity for small companies for sub-sectoral jobs. Take advantage of opportunities to reach consumers, creating competition between similar repair service companies. This also makes every company must innovate a creative marketing strategy in selling services offered to target targets. CV. Roris Teknik is one of the service companies, which was established in 2013 and is engaged in eldoctrinic and electrical repair services. Obstacles that often occur is when the schedule of project work in these circumstances the need for leadership

$\begin{array}{ll}\text { How to cite: } & \text { Mardany, Annysa., Dhadar Wulandari, Yuni Herlinda Hutabarat (2021) Analisis Pengaruh } \\ & \text { Kepemimpinan, Motivasi Dan Disiplin Kerja Terhadap Kinerja Karyawan Cv. Roris Teknik } \\ & \text { Tangerang. Syntax Idea, 3(9), https://doi.org/10.36418/syntax-idea.v3i9.1481 } \\ \text { E-ISSN: } & \text { 2684-883X } \\ \text { Published by: } & \text { Ridwan Institute }\end{array}$


direction, company motivation and good work discipline between fields of work in cv Roris Teknik so that it can follow up employee performance as soon as possible so as not to cause disappointment from consumers. Based on the description above, the author is interested in conducting research that will be poured in the form of scientific writing entitled "Analysis of The Influence of Leadership, Motivation and Work Discipline on Employee Performance CV. Roris Teknik Tangerang"”

Keywords: leadership; motivation and work discipline; employee performance

Received: 2021-08-22; Accepted: 2021-09-05; Published: 2021-09-20

\section{Pendahuluan}

Sumber Daya Manusia (SDM) sangat penting bagi organisasi/perusahaan dalammengatur, mengelola, dan memanfaatkan pegawai sehingga dapat berfungsi secara produktif dalam rangka untuk tercapainya tujuan organisasi. Sumber daya manusia suatu perusahaan perlu dikelola secara benar agar tercipta antara kebutuhan pegawai dengan tuntutan dan kemampuan perusahaan tersebut. Berkembangnya suatu perusahaan sangatlah bergantung pada kualitas kinerja dari tenaga kerja yang ada di perusahaan itu sendiri (Sampurno, Aji, \& Dewi, 2010).

Sumber daya manusia merupakan aset penting bagi organisasi. Mereka membutuhkan perhatian dari berbagai pihak agar prestasinya dapat dimaksimalkan sehingga tujuan organisasi tercapai. Berdasarkan hal tersebut, manajemen sumber daya manusia diperlukan untuk meningkatkan efektivitas sumber daya manusia dalam sebuah organisasi (Supomo \& Nurhayati, 2018).

Sumber daya manusia merupakan faktor sentral dalam pengelolaan suatu organisasi. Dalam mencapai tujuannya, suatu organisasi memerlukan sumber daya manusia sebagai pengelola sistem. Sumber daya manusia yang kompeten dengan kinerja yang baik, dapat menunjang keberhasilan bisnis. Sebaliknya sumber daya manusia yang tidak kompeten dan kinerjanya buruk merupakan masalah kompetitif yang dapat menempatkan perusahaan dalam kondisi yang merugi. Mencapai tujuan suatu organisasi memerlukan sumber daya manusia sebagai pengelola sistem. Agar sistem ini berjalan tentu dalam pengelolaannya harus memperhatikan beberapa aspek penting seperti kepemimpinan, motivasi, lingkungan kerja, kinerja dan aspek-aspek lainnya. Hal ini akan menjadikan manajemen sumber daya manusia sebagai salah satu indikator penting pencapaian tujuan organisasi secara efektif dan efisien (Potu, 2013).

Kata motif sering diartikan sebagai daya dalam diri seseorang untuk melakuklan sesuatu. Motif adalah sebab yang menjadi dorongan tindakan seseorang. Motif diartikan sebagai daya yang mendorong seseorang untuk melakukan sesuatu. Motif dapat dikatakan sebagai daya penggerak dari dalam diri subyek untuk melakukan aktivitsaktivitas tertentu demi mecapai suatu tujuan. Bahkan motif dapat diartikan sebagai kondisi intern. (kesiapsiagaan), berawal dari kata motif itu, makaka motivasi dapat diartikan sebagai daya penggerak yang telah menjadi aktif. Motif menjadi aktif pada saat tertentu, terutama bila kebutuhan untuk mencapai tujuan dapat dirasakan/mendesak (Idzhar, 2016). 
Motivasi merupakan proses pemberian motif (penggerak) bekerja kepada para pegawai sehingga mereka mau bekerja demi tercapainya tujuan perusahaan secara efektif dan efisien. Pemberian motif kerja ini terdapat dalam teori kebutuhan hierarki Maslow yang meliputi kebutuhan fisiologis, kebutuhan keamanan, kebutuhan sosial, kebutuhan penghargaan dan kebutuhan aktualisasi diri (Afianto \& Utami, 2017).

Kepemimpinan efektif memiliki peranan penting dan strategis untuk menentukan efektifitas dan efisiensi pencapaian tujuan kelompok dan organisasional (Sholeh, 2017) motivasi sebagai pendorong atau pengerak perilaku ke arah pencapaian tujuan merupakan suatu siklus yang terdiri dari tiga elemen, yaitu adanya kebutuhan (needs), dorongan untuk berbuat dan bertindak (drives), dan tujuan yang diinginkan (goals). Dorongan tersebut memiliki komponen berupa arah perilaku dan kekuatan perilaku (Kadarisman, 2017). Kepemimpinan yang efektif merupakan salah satu faktor penentu dalam keberhasilan usaha (Sidharta \& Lusyana, 2015).

Disiplin kerja memberikan manfaat yang positif bagi organisasi, karena dengan adanya disiplin kerja dari dalam diri karyawan dapat menyelesaikan tugas sesuai dengan aturan standar kerja dan tepat waktu sesuai yang telah ditentukan (Afianto \& Utami, 2017) menjelaskan mengenai disiplin yaitu sikap dan perilaku kepatuhan terhadap peraturan organisasi, prosedur kerja, kode etik, dan norma budaya organisasi lainnya yang harus dipatuhi.

Kepemimpinan, motivasi dan disiplin kerja dibutuhkan sekali oleh para karyawan CV. Roris Teknik Tangerang mengingat pekerjaan antara satu bidang pekerjaan dengan bidang pekerjaan lainnya saling berkaitan sehingga jika ada salah satu bidang kerja yang mengalami kesalahan dalam bekerja maka semua pekerjaan akan menjadi terhambat.

Kendala yang sering terjadi adalah ketika jadwal proyek IT mengalami keterlambatan pengerjaan, dalam keadaan inilah perlu disiplin kerja yang baik antar bidang kerja Cv.Roris Teknik Tangerang agar bisa di tindak lanjuti sesegera mungkin sehingga tidak menimbulkan kekecewaan dari konsumen. Berdasarkan uraian diatas, maka penulis tertarik untuk mengadakan penelitian yang kemudian akan dituangkan dalam bentuk tulisan ilmiah yang berjudul "Analisis Pengaruh Kepemimpinan, Motivasi Dan Disiplin Kerja Terhadap Kinerja Karyawan Cv.Roris Teknik Tangerang. Tujuan penelitian ini adalah untuk Menganalisi Pengaruh Kepemimpinan, Motivasi dan Disiplin Kerja Terhadap Kinerja Karyawan Cv. Roris Teknik Tangerang.

\section{Metode Penelitian}

Jenis penelitian yang digunakan dalam penulisan ini merupakan penelitian deskriptif, dengan menggunakan pendekatan kualitatif. Penelitian deskriptif adalah suatu bentuk penelitian yang ditujukan untuk mendeskripsikan fenomena-fenomena yang ada, baik fenomena alamiah maupun fenomena buatan manusia. Fenomena itu bisa berupa bentuk, aktivitas, karakteristik, perubahan, hubungan, kesamaan, dan perbedaan antara fenomena yang satu dengan fenomena lainnya (Hamdi \& Bahruddin, 2015).

Populasi pada penelitian ini adalah Lokasi Kegiatan Perusahaan CV. Roris Teknik Tangerang, dimana peneliti meneliti sampel dari keseluruhan populasi yang ada (sample 
jenuh) Teknik pengumpulan observasi yang digunakan adalah participant observation, yaitu dimana peneliti terlibat secara langsung dalam kegiatan sehari-hari pada CV. Roris Teknik Tangerang sebagai sumber data. Teknik pengumpulan dengan cara wawancara yang digunakan adalah wawancara tidak terstruktur, yaitu peneliti hanya memuat poinpoin penting pada kasus CV. Roris Teknik Tangerang dari responden.

\section{Hasil dan Pembahasan}

1. Penerapan Kepemimpinan Dalam Meningkatkan Kinerja

Kepemimpinan di dalam CV. Roris Teknik Tangerang yang efektif tidak dapat tercapai tanpa inklusi penuh, inisiatif dan kerja sama karyawan. Oleh karenanya pemberian arahan telah dilakukan agar karyawan bekerja sesuai dengan SOP.

2. Penerapan Motivasi Dalam Meningkatkan Kinerja

Motivasi sebagai pendorong atau pengerak perilaku ke arah pencapaian tujuan merupakan suatu siklus yang terdiri dari tiga elemen, yaitu adanya kebutuhan (needs), dorongan untuk berbuat dan bertindak (drives), dan tujuan yang diinginkan (goals). Dorongan tersebut memiliki komponen berupa arah perilaku dan kekuatan perilaku (Sarinadi, Tripalupi, \& Suwena, 2015).

3. Penerapan Disiplin Kerja Dalam Meningkatkan Kinerja Karyawan Cv Roris Teknik Tanggerang Kota Tangerang

Selama ini semua karyawan CV. Roris Teknik Tangerang sudah bekerja dengan disiplin yaitu sesuai aturan yang berlaku di perusahaan .selain disiplin waktu dalam bekerja karyawan juga dituntut disiplin dalam bekerja hal ini dilakukan agar meminimalisir keluhan pelanggan seperti hasil service yang baik dan sparepart listrik yang original. agar kesalahan sekecil apapun bisa terhindar, perusahaan CV. Roris Teknik Tangerang akan memberikan sanksi yang tegas terhadap pelanggaran disiplin yang dilakukan karyawan, hal ini dilakukan untuk meminimalisir kerugian perusahaan serta kepuasan konsumen.

4. Penerapan Kepemimpinan,Motivasi Dan Disiplin Kerja Dalam Meningkatkan Kinerja Karyawan CV. Roris Teknik Tangerang Seharusnya

Kepemimpinan menunjukkan suatu hubungan pengaruh antara pemimpin dan pengikut untuk mencapai tujuan bersama dalam situasi tertentu (Pangestika, 2018). Motivasi adalah serangkaian sikap dan nilai-nilai yang mempengaruhi individu untuk mencapai hal yang spesifik sesuai dengan tujuan individu. Sikap dan nilai tersebut merupakan suatu yang invisible yang memberikan kekuasan untuk mendorong individu untuk bertingkah laku dalam pencapaian tujuan (Monica, 2016).

Disiplin kerja merupakan tindakan manajemen mendorong pegawai memenuhi tuntutan berbagai ketentuan tersebut. Pendisiplinan pegawai adalah suatu bentuk pelatihan yang berusaha memperbaiki dan membentuk pengetahuan, sikap dan perilaku pegawai sehingga para pegawai tersebut secara sukarela berusaha berkerja secara kooperatif dengan para pegawai yang lain serta meningkatkan prestasi kerjanya (Rumondor, Tumbel, \& Sepang, 2016). Kepemipinan yang baik memberikan pengaruh 
postif akan kinerja karyawan agar tercipta nya tujuan bersama. Selain itu Motivasi perusahaan berupa reward atau punishment untuk memacu kinerja karyawan agar menghasilkan suatu produk atau jasa yang baik untuk konsumen (Naqiyyah, 2016).

Disiplin kerja memberikan manfaat yang positif bagi organisasi, karena dengan adanya disiplin kerja dari dalam diri karyawan dapat menyelesaikan tugas sesuai dengan aturan standar kerja dan tepat waktu sesuai yang telah ditentukan. Dengan demikian dapat membantu meningkatkan kinerja karyawan. Disiplin kerja yang dapat direalisasikan dengan baik akan dapat mengurangi karyawan dalam melakukan tindakan yang menyimpang.

\section{Kesimpulan}

CV. Roris Teknik Tangerang merupakan perusahaan kecil dibidang jasa perbaikan dan pengadaan kelistrikan di tangerang. Perusahaan ini melakasanakan kepeimpinan yang baik denan karyawan, motivasi karyawan dengan bentuk reward kepada karyawannya. Dan juga Tingkat displin yang baik yang mana sangat minim complain dari para konsumen. 


\section{BIBLIOGRAFI}

Afianto, Izaz Dany, \& Utami, Hamidah Nayati. (2017). Pengaruh disiplin kerja dan komunikasi organisasi terhadap kepuasan kerja dan kinerja karyawan (studi pada karyawan divisi marketing pt. victory international futures kota malang). Jurnal Administrasi Bisnis, 50(6), 58-67.Google Scholar

Hamdi, Asep Saepul, \& Bahruddin, E. (2015). Metode penelitian kuantitatif aplikasi dalam pendidikan. Yogyakarta. Deepublish. Google Scholar

Idzhar, Ahmad. (2016). Peranan guru dalam meningkatkan motivasi belajar siswa. Jurnal Office, 2(2), 221-228. Google Scholar

Kadarisman, Muh. (2017). The Implementation Of Regional Autonomy In Depok City Post-Constitution 1945 Amandment. Imc 2016 Proceedings, 1(1). Google Scholar

Monica, Dian. (2016). Pengaruh Penilaian Kinerja dan Kompensasi Terhadap Kinerja Karyawan pada PT. Guna Layan Kuasa Kantor Cabang Medan. Repository Medan University. Google Scholar

Naqiyyah, Hibah. (2016). Analisis Reward Dan Motivasi Kerja Terhadap Kinerja Karyawan Di Umkm Hafidz Collection Padurenan Gebog Kudus. Repository Stain Kudus. Google Scholar

Pangestika, Novi Kusuma. (2018). Pengaruh Kepemimpinan, Motivasi Dan Disiplin Kerja Terhadap Kinerja Karyawan Lembaga Penyiaran Publik Rri Surakarta. Jurnal Ekonomi Dan Kewirausahaan, 18. Google Scholar

Potu, Aurelia. (2013). Kepemimpinan, motivasi, dan lingkungan kerja pengaruhnya terhadap kinerja karyawan pada Kanwil Ditjen Kekayaan Negara Suluttenggo dan Maluku Utara di Manado. Jurnal EMBA: Jurnal Riset Ekonomi, Manajemen, Bisnis Dan Akuntansi, 1(4). Google Scholar

Rumondor, Rommy Beno, Tumbel, Altje, \& Sepang, Jantje L. (2016). Pengaruh Kepemimpinan, Motivasi, dan Disiplin Kerja terhadap Kinerja Pegawai pada Kanwil Ditjen Kekayaan Negara Suluttenggomalut. Jurnal EMBA: Jurnal Riset Ekonomi, Manajemen, Bisnis Dan Akuntansi, 4(2). Google Scholar

Sampurno, Sampurno, Aji, Awik Abrar, \& Dewi, Indri Kusuma. (2010). Quality Service Analysis Of Pharmacy Department Of Cilacap Local Government Hospital And Muhammadiyah Hospital In Karanganyar. Jurnal Ilmu Kefarmasian Indonesia, 8(2), 101-107. Google Scholar

Sarinadi, Ni Nengah, Tripalupi, Lulup Endah, \& Suwena, Kadek Rai. (2015). Analisis Faktor-faktor yang Mempengaruhi Motivasi Kerja Karyawan pada UD Surya Logam Desa Temukus Tahun 2014. Jurnal Pendidikan Ekonomi Undiksha, 4(1). Google Scholar 
Sholeh, Muhamad. (2017). Keefektifan Peran Kepala Sekolah dalam Meningkatkan Kinerja Guru. JDMP (Jurnal Dinamika Manajemen Pendidikan), 1(1), 41-54. Google Scholar

Sidharta, Iwan, \& Lusyana, Dina. (2015). Pengaruh Orientasi Hubungan Dan Orientasi Tugas Dalam Kepemimpinan Terhadap Kinerja Pelaku Usaha. None. Jurnal Ekonomi, Bisnis \& Entrepreneurship. Google Scholar

Supomo, R., \& Nurhayati, Eti. (2018). Manajemen Sumber Daya Manusia. Jember. Fakultas Ilmu Sosial, Administrasi Publik, Human Resources Management. Google Scholar

\section{Copyright holder:}

Annysa Mardany, Dhadar Wulandari, Yuni Herlinda Hutabarat (2021)

\section{First publication right:}

Syntax Idea

This article is licensed under: 